\title{
Rainwater Interception Pattern of a Regenerated Secondary Tropical Forest and Oil Palm (Elaeis guineensis Jacq.) Canopies in Bintulu, Sarawak
}

\author{
MOHD SALAHUDDIN ROSLAN*¹, GEOFFERY JAMES GERUSU ${ }^{1} \&$ ABU HENA \\ MUSTAFA KAMAL ${ }^{2}$
}

\begin{abstract}
${ }^{1}$ Department of Forestry Science, ${ }^{2}$ Department of Animal Science and Fishery, Faculty of Agriculture and Food Sciences, Universiti Putra Malaysia, Bintulu Sarawak Campus, 97000 Bintulu, Sarawak, Malaysia *Corresponding author: samarendang87@gmail.com
\end{abstract}

\begin{abstract}
Regenerated secondary tropical forest that resulted from logging activity and transforming of forest into oil palm (Elaeis guineesis Jacq.) estate are expected to influence the magnitude of rainfall water fraction under these plant canopies. In depth information and knowledge regarding interception pattern of rainwater are still very much lacking, especially under these canopies in tropical region. Thus, the objective of this study was to evaluate the amount of rainwater passing the regenerated secondary tropical forest and oil palm canopies, which currently cover $14.7 \%$ of the total land area in Malaysia. Three sampling sites were established, which consisted of a regenerated secondary tropical forest (RSTF), productive oil palm plantation (POP) and non-productive oil palm area (NPOP). The computed throughfall $\left(T f_{d}\right)$ for RSTF, POP and NPOP were $77.2 \%, 91.1 \%$ and $87.4 \%$, respectively. The stemflow $\left(S f_{d}\right)$ was worked out as $0.5 \%$ (RSTF), $0.7 \%$ (POP) and $0.4 \%$ (NPOP) of gross rainfall during the study period. The findings revealed that $22.3 \%, 8.2 \%$ and $12.2 \%$ were intercepted by RSTF, POP and NPOP canopies, respectively and evaporated back to the atmosphere. The measured $T f_{d}, S f_{d}$ and evaporation $\left(E_{i}\right)$ were different among the three study sites even within the local environment and thus, suggesting the findings to be influenced by 1) canopy structures and trunk morphology; 2) installation of sampling material; 3) species and age of tree or trunk; and 4) local meteorological condition. The study recommends extra caution should be considered during the installation of sampling material, especially for $S f_{d}$ measurement to avoid leakage and improve the accuracy of $E_{i}$ values. This is important because the portion of rainwater intercepted by these canopies is a significant component, which is vital for managing forest resources, oil palm estate, as well as catchment area for sustainable clean water resources.
\end{abstract}

Keywords: Interception loss, oil palm, rainfall, regenerated secondary tropical forest, Sarawak

Copyright: This is an open access article distributed under the terms of the CC-BY-NC-SA (Creative Commons Attribution-NonCommercial-ShareAlike 4.0 International License) which permits unrestricted use, distribution, and reproduction in any medium, for non-commercial purposes, provided the original work of the author(s) is properly cited.

\section{INTRODUCTION}

The inter-relating effects on plant ecology and the environment is essential to increase the awareness for better management of agricultural land uses. One of the important alterations in hydrological fluxes resulting from forest conversion is the amount of water intercepted by and re-evaporated from vegetation surfaces. This interception loss of rainfall is believed to play an important role in the water balance of catchments and plant ecosystems. Furthermore, to improve catchment and water resources management, understanding on hydrological processes such as rainfall interception, throughfall and stemflow were very important especially under oil palm canopy (Geoffery, 2013). As tropical rainforest receives great variability in stemflow and throughfall
(Lloyd \& Marques, 1988; Marin et al., 2000), factors attributed to climatic conditions, species composition, monitoring methodology (Germer et al., 2010), structure of tree canopy and multiple data collections (Junior et al., 2015) are necessary for investigating the rainfall interception of forest canopy. There were some queries remain concerning the relative importance of various mechanisms for interception loss process especially from old oil palm stands and regenerated secondary tropical forest. Generally, interception loss rates vary among tree species, forest density, canopy structure, vegetation physiology and different climatic conditions (Zhang et al., 2006). A number of studies on interception loss had been conducted but a detailed relationship with vegetation has yet to be documented (Dietz et al., 2006; Slamet et al., 2015). 
Information on the rates of interception loss are of importance in determining the water yield of forested areas (Gash \& Stewart, 1977; Scatena, 1990; Loustau et al., 1992). Other researchers pointed out that forest conversion to other vegetation cover and reduction of forest canopy cover are the main determinants of the difference in water balance, which resulted in an increment in the catchment water yield (Sahin \& Hall, 1996). It has been suggested that the rainfall interception loss measurements and models are prerequisites for any quantitative predictions of the effects of forest management on local hydrology (Asdak et al., 1998).

Malaysia is blessed with abundant natural resources and a conducive climate for commercial cultivation of crops such as oil palm. In a relatively short period of time, Malaysia has become a major palm oil producer and exporter. In 2016, Malaysia accounted for $39 \%$ of the world palm oil production and $44 \%$ of world exports. Being one of the biggest producers and exporters of palm oil and palm oil products, Malaysia has an important role to play in fulfilling the growing global need for cooking oil and fats sustainably. From about 400 hectares planted in 1920, the area had increased to 54,000 hectares in 1960. Since then, many more areas were opened up for oil palm cultivation, either from virgin jungles or from conversion of plantations that originally supported rubber or other crops (Abdullah \& Nakagoshi, 2007). In 2004 , the area covered by oil palm stood at a staggering 3.87 million ha representing 70-fold increase since 1960's (Md Noor \& Harun, 2004). This represents about $60 \%$ of the total 6.08 million ha designated for agriculture under the National Agriculture Plan (NAP3) 1998-2010 (Yusof \& Chan, 2004). Thus, about $14.7 \%$ of Malaysia's total land mass is currently covered by oil palm plantations.

Conversely, literature on rainwater interception loss from oil palm tree has received low priority for scientific study and so far, no scientific finding on regenerated secondary tropical forest is available. In this context, this study aimed to assess rainwater interception losses and storage rates under varied canopies structures namely regenerated secondary tropical forest (RSTF), productivity oil palm (POP) and non-productivity oil palm (NPOP) canopies.

\section{MATERIALS AND METHODS}

\section{Study Area}

The research activity was carried out in three locations under different canopies cover, namely regenerated secondary tropical forest (RSTF), productive oil palm plantation (POP) and nonproductive oil palm plantation (NPOP) (Figure 1). These experimental sites are situated within Universiti Putra Malaysia (UPM) Bintulu Sarawak Campus, Bintulu, Sarawak, Malaysia. The RSTF is situated within a Forest Park $\left(3^{\circ} 12^{\prime} 30.73^{\prime \prime} \mathrm{N}, 113^{\circ} 05^{\prime} 53.02^{\prime \prime} \mathrm{E}\right)$ that was 46 meters above the sea level. The POP and NPOP study sites are located approximately at $3^{\circ} 12^{\prime} 19.11^{\prime \prime} \mathrm{N}, 1^{\circ} 113^{\circ} 03^{\prime} 57.74^{\prime \prime} \mathrm{E}$ and $3^{\circ} 12^{\prime} 24.01^{\prime \prime} \mathrm{N}, 113^{\circ} 03^{\prime} 53.01^{\prime}$ ' E, respectively. The oil palm area is undulating with the altitude ranging from 43 to $62 \mathrm{~m}$ above the sea level. Slopes are moderate for all study sites with the maximum slopes of $21^{\circ}$.

The 30 hectares of RSTF was covered with mixed lowland dipterocarp and non-dipterocarp species. The mean basal area of trees was about $38 \mathrm{~m}^{2} \mathrm{ha}^{-1}$ with an average diameter at breast height $(\mathrm{DBH})>31 \mathrm{~cm}$. The geology of the study site is mainly Nyalau formation of OligoceneMiocene period (Geoffery \& Yusop, 2005). The total area of POP is only about 5 hectares and NPOP is about 65 hectares. Both areas were planted with Elaeis guineensis Jacq. (clone PAMOL/FELDA). Genus Elaeis belongs to family Palmae and indigenous to West Africa (Hartley, 1988). The mean trunk heights were about $2.43 \mathrm{~m}$ and $5.1 \mathrm{~m}$ for POP and NPOP, respectively. The average trunk diameter was $64.6 \mathrm{~cm}$ for POP and $48.3 \mathrm{~cm}$ for NPOP. The average top height of POP and NPOP were $7.0 \mathrm{~m}$ and $15.0 \mathrm{~m}$, respectively. The canopy cover was quite uniform, between 80 and $88 \%$ of the ground area. The leaf area index (LAI) normally increases with the palm age and reaches a maximum after about 10 years (Corley \& Gray, 1976). The LAI values for oil palm trees on a highly fertile site, with planting density of 148 palm ha ${ }^{-1}$ range from 5.9 to 7.1 (Md Noor \& Harun, 2004). The total basal area for POP was about $50 \mathrm{~m}^{2} \mathrm{ha}^{-1}$ with the average diameter at DBH of greater than $63 \mathrm{~cm}$. However, the total basal area for NPOP is lower, which was about $42 \mathrm{~m}^{2} \mathrm{ha}^{-1}$ and the average DBH $<45 \mathrm{~cm}$. The climate of the study areas is typical to the humid tropics, with a small variation of the mean daily 


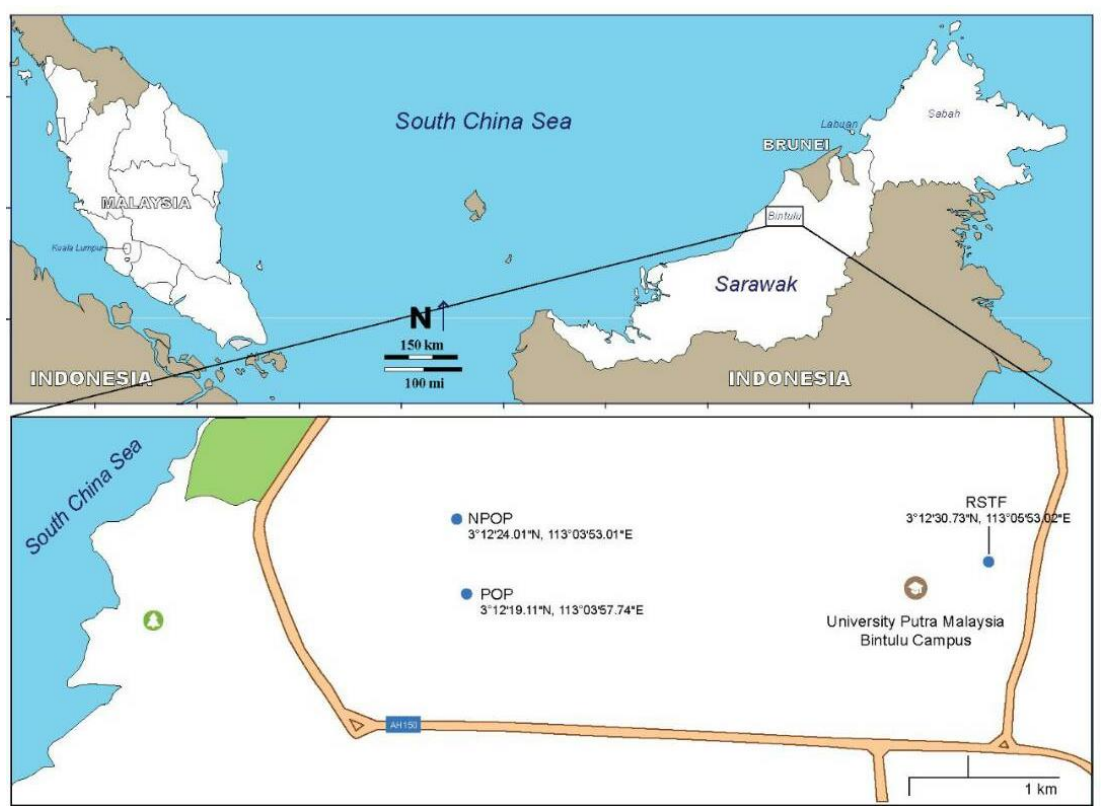

Figure 1. Location of research areas at regenerated secondary tropical forest (RSTF), productive oil palm (POP) and non-productive oil palm (NPOP) in Bintulu, Sarawak (Source: Google Maps).

temperature $\left(25-26^{\circ} \mathrm{C}\right)$ in any month. The relative humidity was typically $100 \%$ at night but occasionally falls below $80 \%$ in the middle of the day.

\section{Field Measurements}

\section{Rainfall}

A $0.2 \mathrm{~mm}$ tipping-bucket rain gauge model HOBO ONSET RGM-2(US) was used to monitor the rainfall event. To determine for an event, rainfall data must be recorded within half an hour at a depth of approximately $0.5 \mathrm{~mm}$ (Germer et al., 2010). In addition, rainfall events were considered as separate event if the time between events exceeded 5 hours (Deguchi et al., 2006). The HOBO rain gauge was recorded when momentary contact-closure events happened, storing the date and time of each event in the logger and retrieving on a weekly basis using BoxCar Pro software that was designed to work with Onset Data Loggers. For the analysis, the rainfall was compared with long-term rainfall data from adjacent rainfall monitoring station.

\section{Throughfall}

Throughfall $(T F)$ was collected by using $1.5 \mathrm{~L}$ polyethylene bottles with a funnel of $84 \mathrm{~mm}$ diameter. Each sampling bottle was covered with a nylon screen $(0.5 \mathrm{~mm}$ mesh), which was placed in the funnel hole to prevent the entry of insects and litterfall. All bottles and funnels were washed by distilled water to make sure they are cleaned. Thirty units of throughfall manual collectors were installed with a minimum 1-m interval in a straight line under canopy at each site to gain more representative data (Geoffery, 2013). Each collector was hanged about $1 \mathrm{~m}$ above ground attached on bamboo stick to avoid splash of rain water at the ground enter the container.

\section{Stemflow}

Stemflow $(S F)$ were collected using spiral-type gauges comprising of a plastic hose $(2.0 \mathrm{~cm}$ internal diameter) attached to the tree and oil palm trunks and routed into 65 litres collecting tank. The sample trees from RSTF areas were selected during a pre-site survey to resolve the uneven distribution of tree diameter sizes. The sample trees were selected based on tree diameter at $\mathrm{DBH}$, irrespective of tree species or bark texture. Eleven trees were selected for $S F$ measurement under the RSTF areas, of which the trees consisted of four species, namely Litsea castanea, Artocarpus anisophyllus, Palaquium clarkeanum and Shorea xanthophylla. However, five oil palm trunks for each of POP and NPOP study areas were selected based on the physical condition of the palm oil tree. The physical characteristics of these selected sample trees and oil palm tree trunks are summarised in Table 1.

Installation of plastic hose to oil palm trunk was initially done by shaving the frond bases surrounding the trunk circumference to provide a clean and smooth surface. The plastic hose needs 
Table 1. Physical characteristics of the measured trees and oil palm trunks.

\begin{tabular}{ccccccc}
\hline $\begin{array}{c}\text { Plant } \\
\text { Types }\end{array}$ & $\begin{array}{c}\text { Mean } \\
\text { diameter } \\
\text { DBH }(\mathrm{cm})\end{array}$ & $\begin{array}{c}\text { Mean canopy } \\
\text { diameter }(\mathrm{m})\end{array}$ & $\begin{array}{c}\text { Dominant tree canopies } \\
\text { at plot site }\end{array}$ & $\begin{array}{c}\text { Canopy } \\
\text { Projection } \\
\text { Area }\left(\mathrm{m}^{2}\right)\end{array}$ & $\begin{array}{c}\text { Stem } \\
\text { condition }\end{array}$ & $\begin{array}{c}\text { Stem bark } \\
\text { condition }\end{array}$ \\
\hline RSTF & 11.6 & 5.08 & Shorea xanthophylla & 20.25 & Straight & Rather rough \\
RSTF & 17.8 & 5.15 & Litsea castanea & 22.82 & Straight & $\begin{array}{c}\text { Smooth } \\
\text { RSTF }\end{array}$ \\
24.8 & 4.52 & Artocarpus anisophyllus & 25.32 & Straight & Smooth \\
RSTF & 39.6 & 7.08 & Palaquium clarkeanum & 29.71 & Straight & Flaky \\
POP & 69.0 & 10.23 & Elaeis guineensis Jacq. & 35.47 & Straight & Rough \\
NPOP & 44.0 & 9.89 & Elaeis guineensis Jacq. & 31.15 & Straight & Rough \\
\hline
\end{tabular}

Notes: RSTF=regenerated secondary tropical forest; $\mathrm{POP}=$ productive oil palm plantation; NPOP=non-productive oil palm area.

to be inspected and maintained on a regular basis as the sampling device was not always entirely satisfactory due to the risk of leakage or blockage. Thus, a silicon sealant was used to seal the hose to the tree bark and oil palm trunk in order to make sure the rainwater did not leak through the tubing. Similarly, SF tanks were emptied on an event basis. The rainwater collected in the tank must be measured by using 1 L measuring cylinder for accurate measurement.

Samples were measured strictly six hours after the rainfall event ceased in order to prevent the mixing of rainwater samples with rainfall from other events.

\section{Data Analysis}

Rainfall and RSTF measurement were recorded from January to December 2016 which accounted for about 138 events. POP measurement samples were taken from January until April 2016 and collected in 15 events. NPOP measurement was collected in 55 events from August to December 2016.

Throughfall and stemflow parameters were used to determine the interception loss ratio of the individual plants or group of species. This study used the following terms for the analyses:

$\mathrm{A}=$ Canopy area projection $\left(\mathrm{m}^{2}\right)$

$\mathrm{B}=$ Basal area $\left(\mathrm{mm}^{2}\right)$

$\mathrm{C}_{\mathrm{A}}=$ Open surface area of manual collector $\left(\mathrm{mm}^{2}\right)$

$\mathrm{E}_{\mathrm{i}}=$ Interception loss

$\mathrm{I}_{\mathrm{R}}=$ Interception loss ratio

$\mathrm{R}_{\mathrm{d}}=$ Rainfall depth (mm)

$\mathrm{Sf}_{\mathrm{y}}=$ Stemflow yield $(\mathrm{L})$, of which stemflow volume dropped in a manual collector and converted into unit $\left(\mathrm{m}^{3}\right)$
$\mathrm{Tf}_{\mathrm{y}}=$ Throughfall yield $(\mathrm{mL})$, of which throughfall volume dropped in a manual collector and converted into unit $\left(\mathrm{mm}^{3}\right)$.

I. Throughfall depth, $T f_{d}$ was defined as throughfall per area of manual collector $\left(\mathrm{mm}^{2}\right)$. The throughfall depth was defined by (Germer et al., 2010):

$T f_{d}=T f_{y} / C_{A}$

(Equation 1)

II. Stemflow depth, $S f_{d}$ was defined as stemflow per area of canopy diameter $\left(\mathrm{m}^{2}\right)$. The stemflow depth was defined by (Germer et al., 2010):

$S f_{d}=S f_{y} / A$

(Equation 2)

III. Interception loss, $E_{i}=\left(R_{d}-T f_{d}-S f_{d}\right)$

(Equation 3)

IV. Interception loss ratio, $I_{R}=\left[\left(R_{d}-T f_{d}-S f_{d}\right) /\right.$ $\left.R_{d}\right] \times 100 \%$

(Equation 4)

V. Stemflow funneling ratio $\left(S_{F R}\right)$ : $S f_{y} /\left(R_{d} \times B\right)$ and unitless (Herwitz, 1986)

(Equation 5)

\section{RESULTS AND DISCUSSION}

\section{Rainfall Characteristics}

Throughout the measurement period, the study site encountered continual rainfall recorded without any outward separation in between the individual events. The individual rainfall event recorded from preceding and succeeding rainfall was separated from each other at least six hours in order to dry the wet canopy (Murakami, 2006). The gross total rainfall during one-year study period amounted to $2466.9 \mathrm{~mm}$ (Figure 2), which was lower than the 3-years of long-term mean annual rainfall of $3423.9 \mathrm{~mm}$. During southwest monsoon (May-September), the observed rainfall was $894.6 \mathrm{~mm}$, which was $1197.6 \mathrm{~mm}$ lower than usual, whereas northeast monsoon (OctoberMarch) rainfall was found to be $1326.2 \mathrm{~mm}$ and this was $1880.2 \mathrm{~mm}$ lower than usual. A total of 


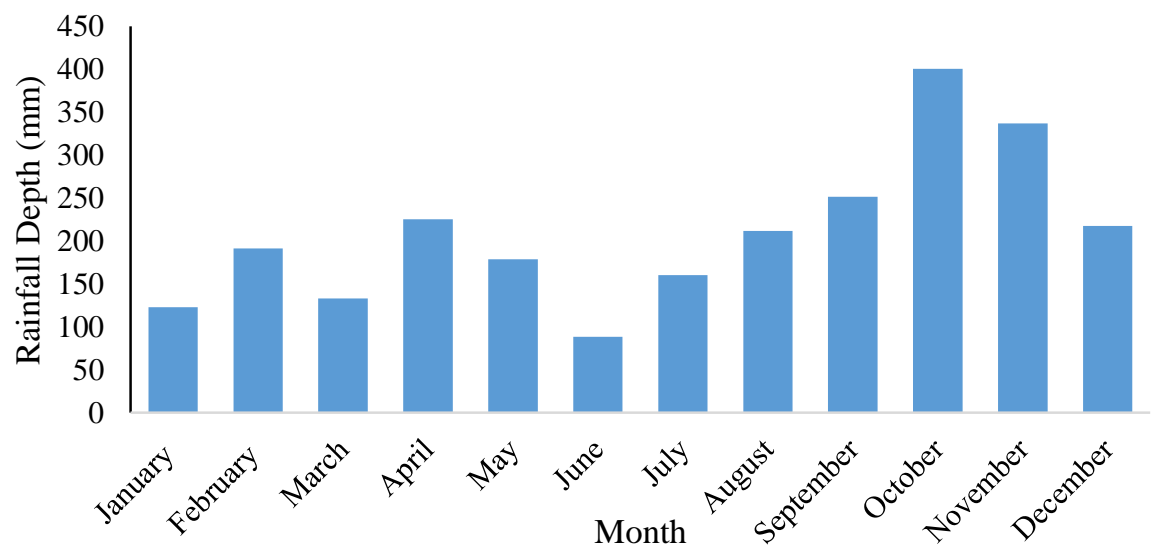

Figure 2. Annual rainfall events of year 2016 at Universiti Putra Malaysia, Bintulu campus.

210 individual rainfall events were recorded, which showed the numbers of rainy day during the study period were similar to the usual rainy day of 211 days. Although the numbers of rainy days almost similar, the quantity of rainfall within the study areas was $27 \%$ lower compared to the normal annual rainfall.

These rainfall events were then divided into five classes: $<5 \mathrm{~mm}, 6-10 \mathrm{~mm}, 11-20 \mathrm{~mm}, 21$ $50 \mathrm{~mm}$ and above $51 \mathrm{~mm}$ (Table 2). Most of the rainfall events were under the category of $<5$ $\mathrm{mm}$, contributing $174 \mathrm{~mm}$ of total annual rainfall. Small rainfall event $(<5 \mathrm{~mm})$ occurred frequently compared to other rainfall classes. However, this small rainfall event only contributed $6.91 \%$ of the total rainfall. Although only eight heavy storms (> $50 \mathrm{~mm}$ ) were recorded, they accounted for $19.22 \%$ of the annual rainfall. These recorded heavy storms mostly occurred during northeast monsoon (October-March) where the wind blew from the South China Sea. As such, the rainfall pattern during the study period could be described as moderate to slightly heavy.

\section{Throughfall Depth}

Throughfall depth $\left(T f_{d}\right)$ measurement were based on the selected rainfall events throughout the study period. The selected rainfall events were based on two criteria: 1) rainfall should be above $1 \mathrm{~mm} / \mathrm{hr}$ to avoid less accuracy when dealing with very small rainfall depth $(<1 \mathrm{~mm})$. According to Department of Irrigation and Drainage Malaysia (DIDM), gross rainfall below $1 \mathrm{~mm} / \mathrm{hr}$ is considered as 'no rain'; 2) a continuous and long-hour rainfall event, which is considered unusual will be excluded to evade error. Therefore, 138, 15 and 55 rainfall events were carefully selected to compute interception loss under RSTF, POP and NPOP. The total $T f_{d}$ depth calculated from these different canopies amounted to about $77.3 \%, 91.1 \%$ and $87.4 \%$, respectively of total selected rainfall from each study areas (Table 3). Based on the regression analysis, all $T F$ measurements from each study

Table 2. The frequency and total rainfall based on five different rainfall classes.

\begin{tabular}{lccc}
\hline Rainfall Classes $(\mathrm{mm})$ & Events Frequency $(\%)$ & Gross Rainfall $(\mathrm{mm})$ & Volume contribution to annual rainfall $(\%)$ \\
\hline Below 5 & 49.05 & 174 & 6.91 \\
$6-10$ & 13.81 & 228.6 & 9.07 \\
$11-20$ & 15.24 & 445.4 & 17.68 \\
$21-50$ & 18.10 & 1187.4 & 47.13 \\
Above 51 & 3.81 & 484.2 & 19.22 \\
Overall total & 100 & 2519.6 & 100 \\
\hline
\end{tabular}

Table 3. The percentage of rainwater passing through RSTF, POP and NPOP.

\begin{tabular}{lccc}
\hline Study Area & $R_{d}$ event $(\mathrm{mm})$ & Total $T f_{d}(\mathrm{~mm})$ & Percentage $(\%)$ \\
\hline RSTF & 2466.9 & 1906.0 & 77.3 \\
POP & 385.8 & 351.5 & 91.1 \\
NPOP & 1144.0 & 999.7 & 87.4 \\
\hline
\end{tabular}

Notes: RSTF=regenerated secondary tropical forest; $\mathrm{POP}=$ productive oil palm plantation; NPOP=non-productive oil palm area. 
site was highly correlated with the amount of rainfall (Figure 3). The empirical relationships for each regression analysis are given by Equation $6 \mathrm{a}, 6 \mathrm{~b}$ and $6 \mathrm{c}$. The results suggested that these equations can be used to estimate $T f_{d}$ under RSTF and oil palm canopies with similarity of physiographic conditions and plants characteristics.

$$
\begin{aligned}
& T f_{d}(\mathrm{RSTF})=0.826 R_{d}-1.243 ; \mathrm{R}^{2}=0.988 \\
& \text { (Equation 6a); } \\
& T f_{d}(\mathrm{POP})=0.979 R_{d}-1.749 ; \mathrm{R}^{2}=0.985 \\
& \text { (Equation 6b); } \\
& T f_{d}(\mathrm{NPOP})=0.840 R_{d}+0.972 ; \mathrm{R}^{2}=0.992 \\
& \text { (Equation 6c); }
\end{aligned}
$$
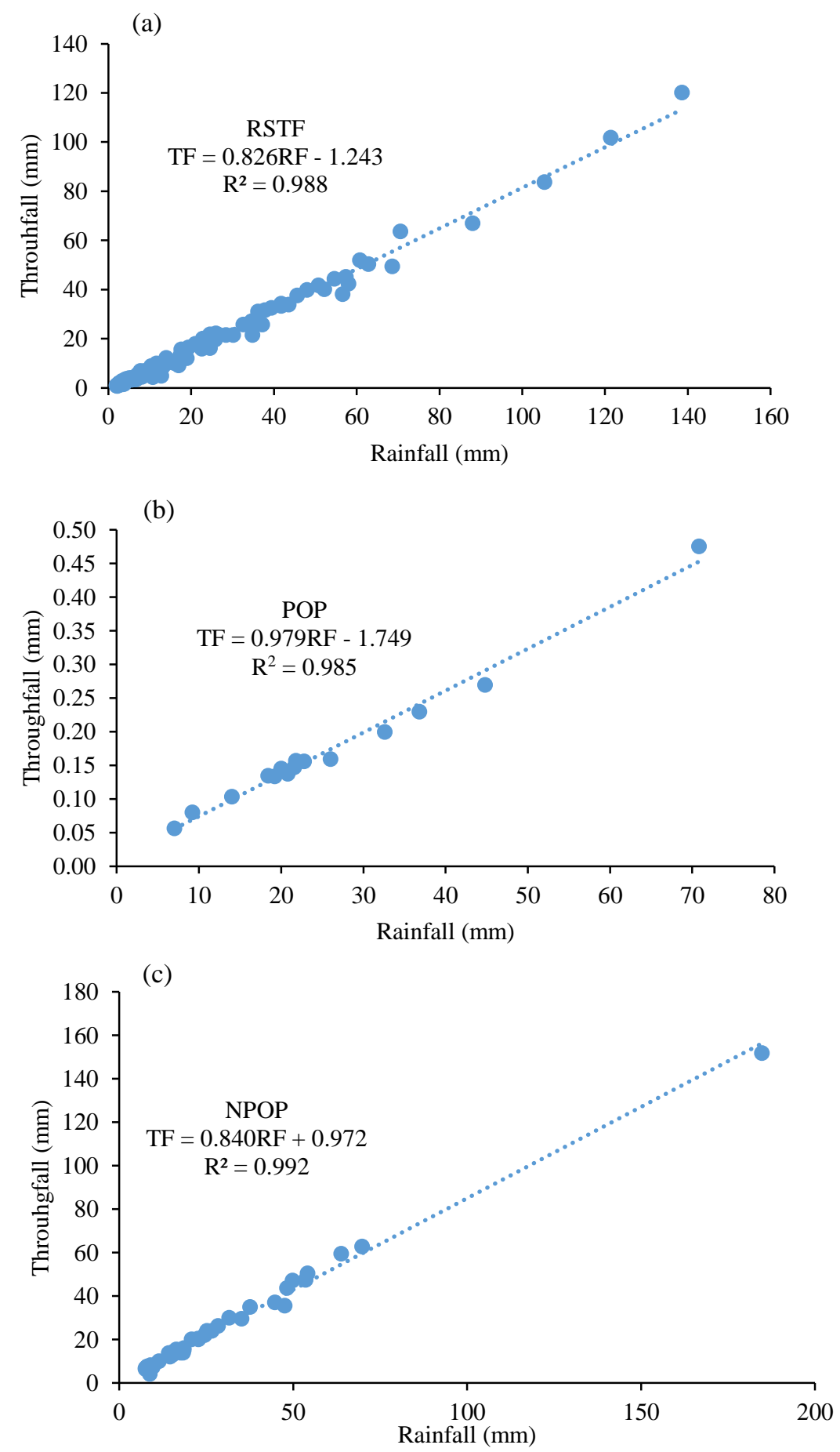

Figure 3. Regression of $T f_{d}$ against $R_{d}$ for (a) regenerated secondary tropical forest (RSTF); (b) productive oil palm plantation (POP); and (c) non-productive oil palm area (NPOP). 
The highest and lowest $T f_{d}$ recorded during the study period are summarised in Table 4 . For an individual event, the ratio of $T f_{d}$ to rainfall ranged widely for RSTF $(32.8-96.2 \%)$ and NPOP (47.2 - 96.6\%). However, POP area showed less variation in term of $T f_{d}$ ratio to rainfall $(70.6-98.6 \%)$. These variations of findings can be explained based on two mechanisms that affect the $T f_{d}$ rates after the canopies wet-up: 1) occurrence of evaporation of stored water on canopy during the storm (Crockford \& Richardson, 1990) and 2) the variability of throughfall depth caused by the characteristics of foliage (Reid \& Lewis, 2009).

In addition, both RSTF and NPOP have similar pattern of $T f_{d}$ ratio against $R_{d}$ where the wide range might be due to the characteristics of the canopy structures. Figure 4 shows the relationship between throughfall depth and rainfall individual event. It is shown that the values were scattered and concentrated around the smaller rainfall sizes. This pattern can be associated with the recorded $R_{d}(80.8 \%)$ that comprises of rain depth of less than $50 \mathrm{~mm}$. Other studies within different forest types (mixed white oak forest - Silva \& Okumura, 1996; deciduous broad-leaves forest - Deguichi et al., 2006) found almost a similar pattern in the relationship between rainfall size and $T F(\%)$.

The $T f_{d}$ value of $91.1 \%$ for POP obtained from this study was slightly higher compared to the finding by Banabas et al. (2008) in Papua New in which the $T f_{d}$ measured was $83 \%$ for productive oil palm canopy. Other studies by Geoffery (2013) in Johor, Malaysia, however revealed lower $T f_{d}$ values of $67 \%$ and $70 \%$, respectively, under productive oil palm canopies. The variations of $T f_{d}$ values among these studies could be attributed to two factors as suggested by Geoffery (2013). Firstly, the orientation of the fronds above the $T f_{d}$ collectors at a particular time may vary due to wind effect during the rainfall event. Secondly, the overlapping canopies might probably become the shelter and therefore reduce the $T f_{d}$ dripping point. However, the $T f_{d}$ values measured under RSTF and NPOP were relatively difficult to compare as no study has yet to be conducted under these canopies in tropical regions.

\section{Stemflow Depth}

The estimated total stemflow depth $\left(S f_{d}\right)$ for RSFT, POP and NPOP study areas were $0.5 \%$, $0.7 \%$ and $0.4 \%$, respectively of total rainwater that reached the ground (Figure 5). The $S f_{d}$ pattern of three different sites obtained from the study were considered very low compared to other studies. For POP study area, the measured $S f_{d}$ of $0.7 \%$ of total rainfall appeared very low as compared to Kee et al. (2000), Banabas et al. (2008) and Geoffery (2013) that were 13\%, 11\% and $4.2 \%$, respectively. Low volume of $S f_{d}$ measured during the study could be related to the sampling method and high absorbance of the oil palm trunks as suggested by Geoffery (2013). The variation of measured $S f_{d}$ is difficult to compare, mainly due to the differences of sample trunk and canopy characteristics. However, low $S f_{d}$ rate is favourable as high $S f_{d}$ yields may leach fertiliser from the soil at trunk base (Schroth et $a l .$, 1999). In addition, Levia and Frost (2003) also reported that $S f_{d}$ might have considerable effect on plant productivity and yield because of its capacity to leach fertilisers near plant stem.

The measured $S f_{d}$ at RSTF and NPOP are less correlated with individual rainfall, compared to POP which is highly correlated as illustrated in Figure 6 and Equation 7a, 7b and 7c. The variation of correlation among RSTF, NPOP and POP might be associated with their stemflow funneling ratio $\left(S_{\mathrm{FR}}\right)$ value introduced by Herwitz (1986) that quantifies the ratio of stemflow yield to gross rainfall and basal area. $\mathrm{S}_{\mathrm{FR}}$ indicates more details of the plants or tree trunks that can capture gross rainfall and generating stemflow (Siegert \& Levia, 2014). $\mathrm{S}_{\mathrm{FR}}>1$, denotes that the $S f_{d}$ volume is yielded directly from the plants canopy and other components and it funnels the rainwater towards its stem. The other components of trees, include branches and

Table 4. The $T f_{d}$ pattern at RSTF, POP and NPOP.

\begin{tabular}{lccc}
\hline Study Area & $T f_{d}$ highest $(\mathrm{mm})$ & $T f_{d}$ lowest $(\mathrm{mm})$ & $\begin{array}{c}\text { Range of ratio } T f_{d} \text { vs. } R_{d} \\
(\%)\end{array}$ \\
\hline RSTF & & & $32.8-96.2$ \\
POP & 120.0 & 0.7 & $70.6-98.6$ \\
NPOP & 69.8 & 6.9 & $47.2-96.6$ \\
\hline
\end{tabular}

Notes: RSTF=regenerated secondary tropical forest; $\mathrm{POP}=$ productive oil palm plantation; NPOP=non-productive oil palm area; $T f_{d}=$ throughfall depth. 
epiphytic plants that grow on the tree stems or oil palm trunks. Based on the computed funneling ratio (Table 5) for the three study sites, POP revealed that $100 \%$ of FR values were $>1$. Low correlation of $S f_{d}$ in RSTF was due to different height of canopies and the overlapping of other plants that were adjacent to the sample tree.

$$
\begin{aligned}
& S f_{d}(\mathrm{RSTF})=0.0033 R_{d}+0.0301 ; \mathrm{R}^{2}=0.476 \\
& \text { (Equation 7a); } \\
& S f_{d}(\mathrm{POP})=0.0062 R_{d}+0.0121 ; \quad \mathrm{R}^{2}=0.986 \\
& \text { (Equation 7b); } \\
& S f_{d}(\mathrm{NPOP})=0.0013 R_{d}+0.0286 ; \mathrm{R}^{2}=0.208
\end{aligned}
$$

(a)

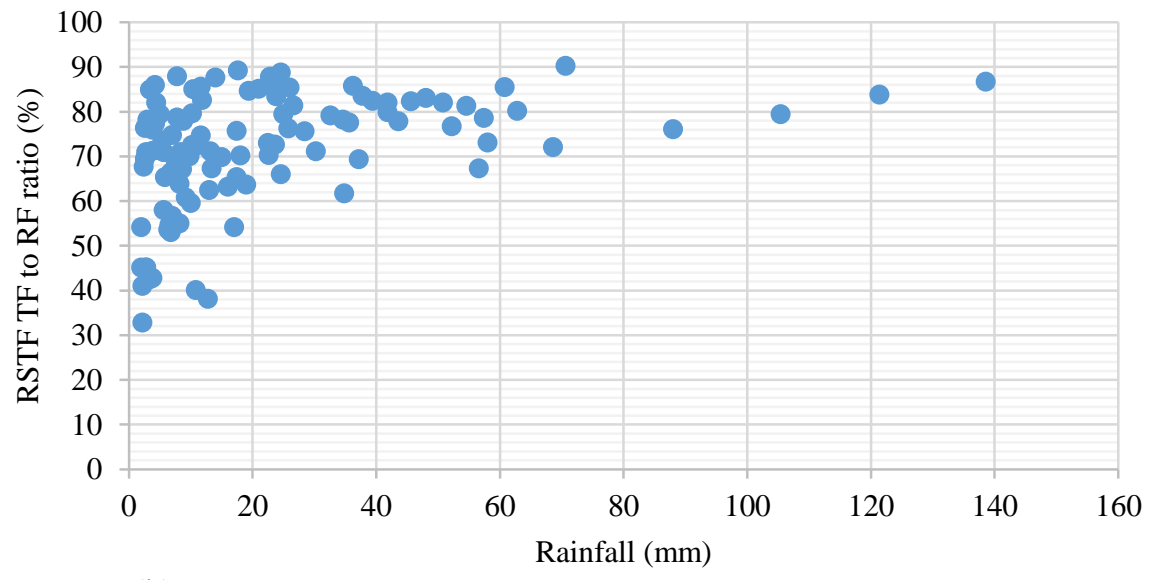

(b)

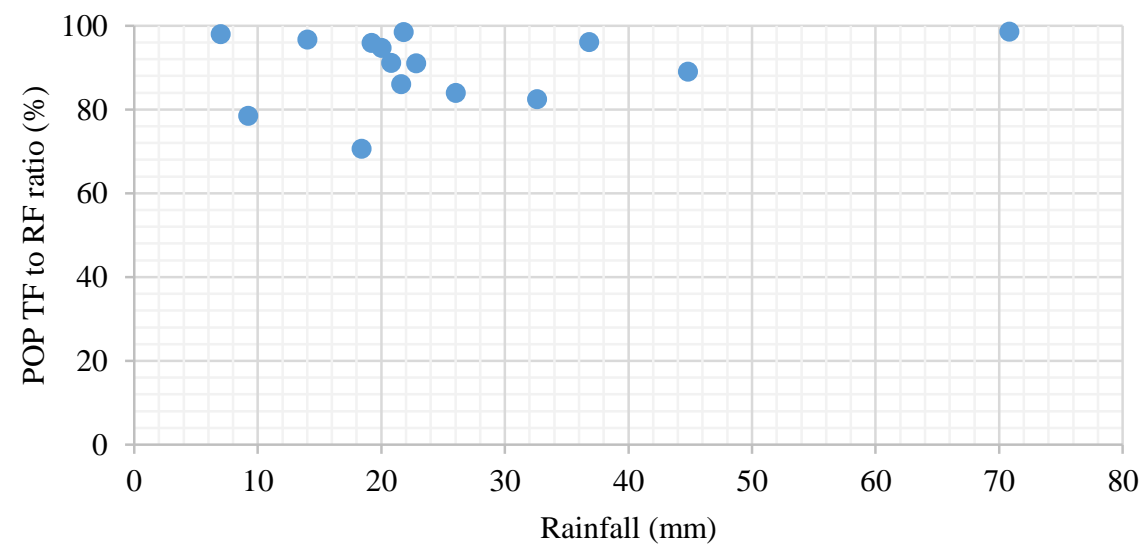

(c)

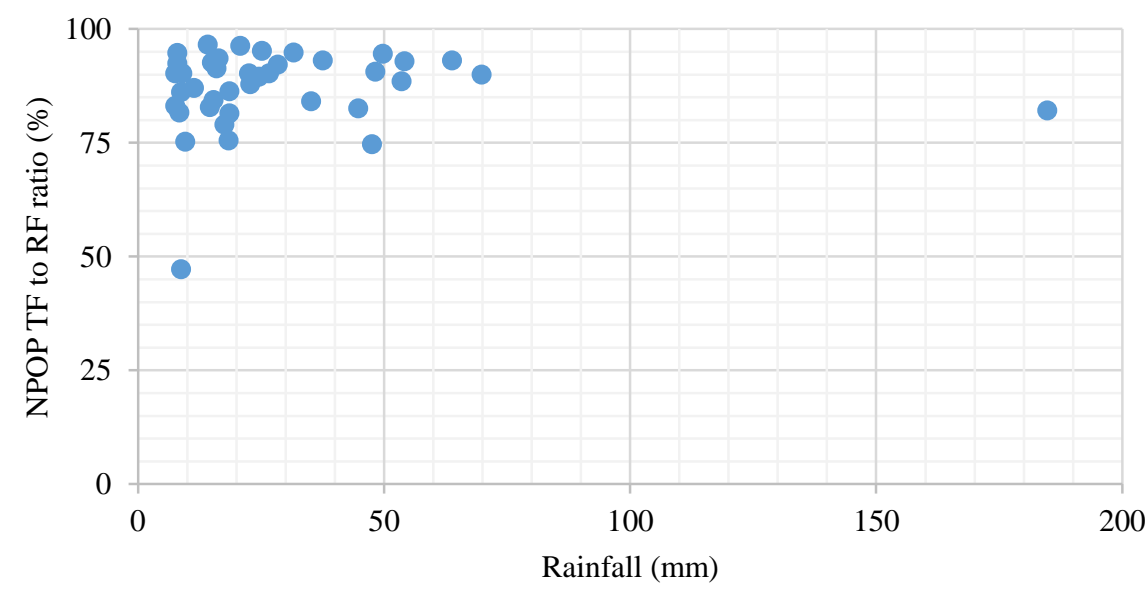

Figure 4. The relationship between $T f_{d}(\%)$ and $R_{d}(\mathrm{~mm})$ for (a) regenerated secondary tropical forest (RSTF); (b) productive oil palm plantation (POP); and (c) non-productive oil palm area (NPOP). 
(a)

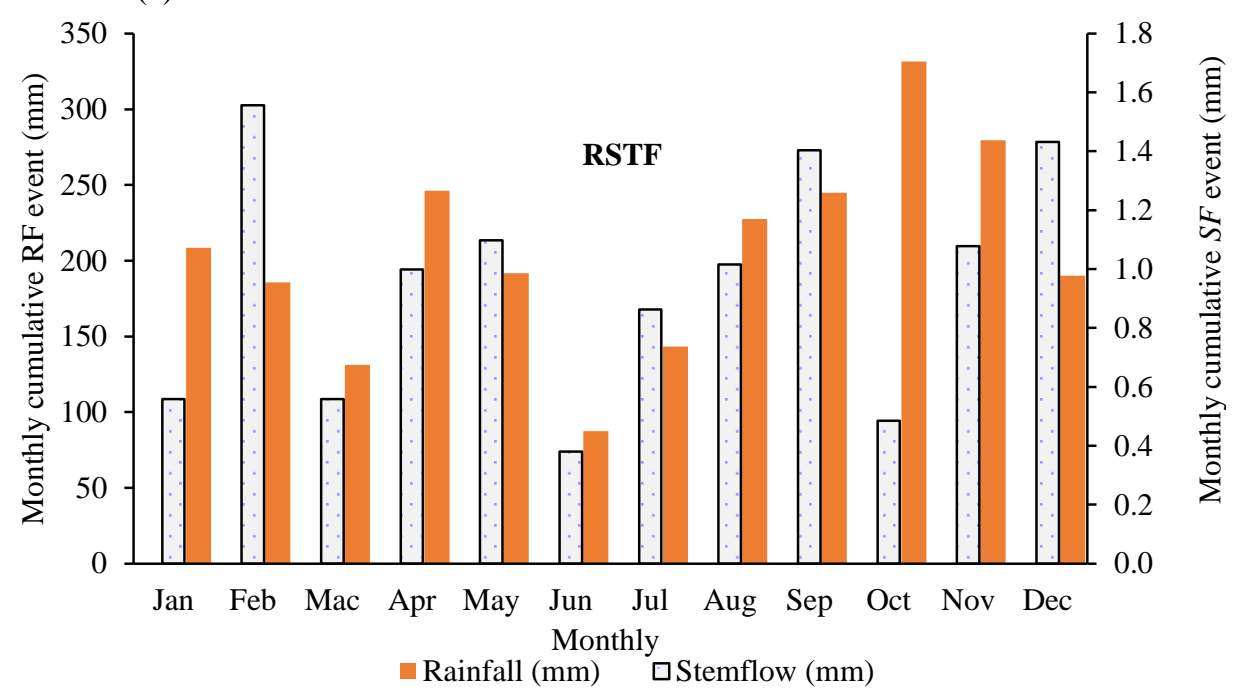

(b)

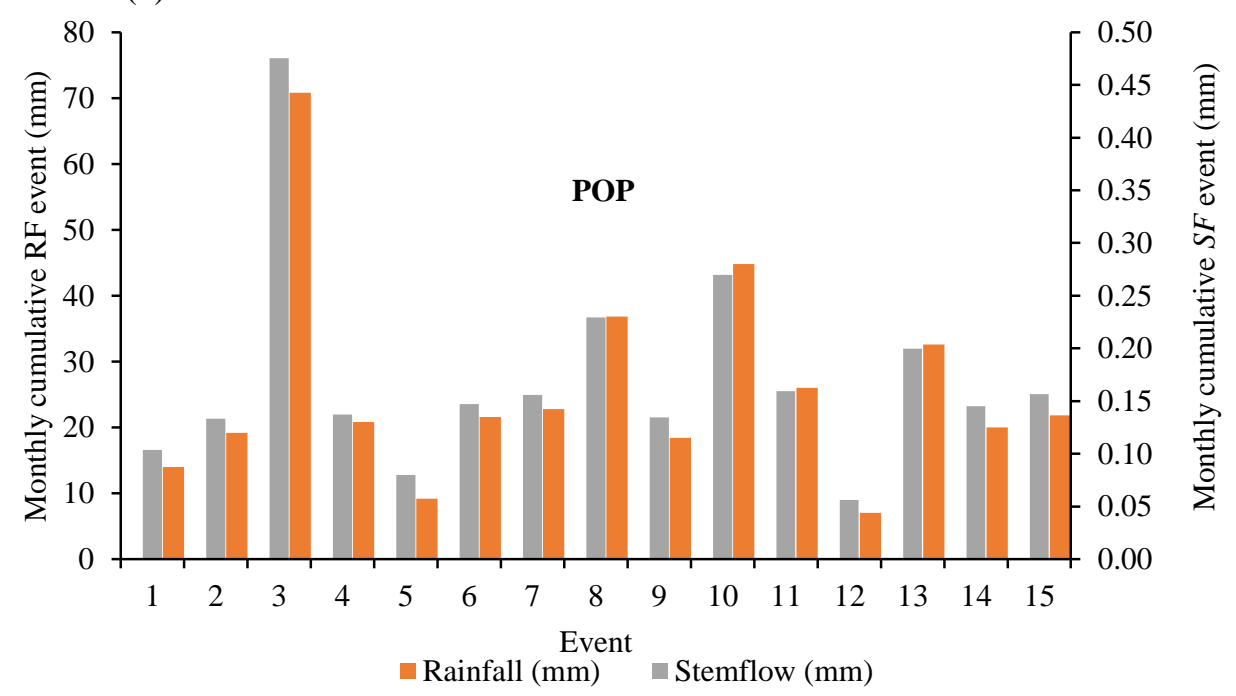

(c)

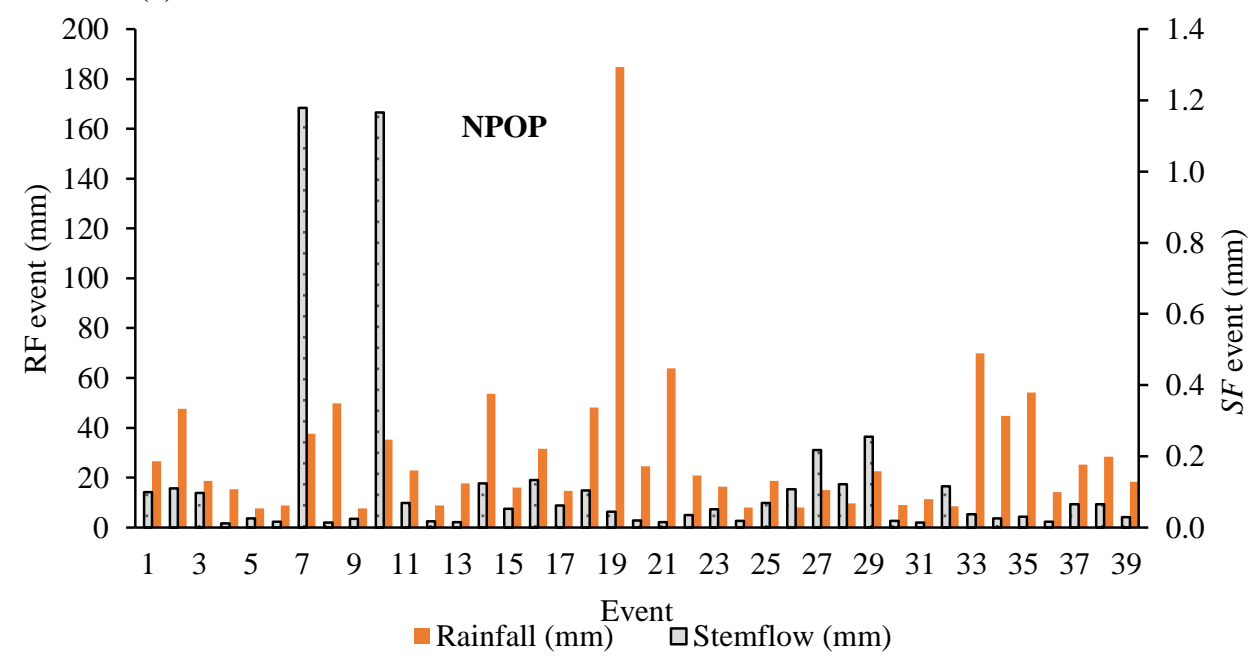

Figure 5. The $S F$ pattern compared to $R F$ event for (a) regenerated secondary tropical forest (RSTF); (b) productive oil palm plantation (POP); and (c) non-productive oil palm area (NPOP). 

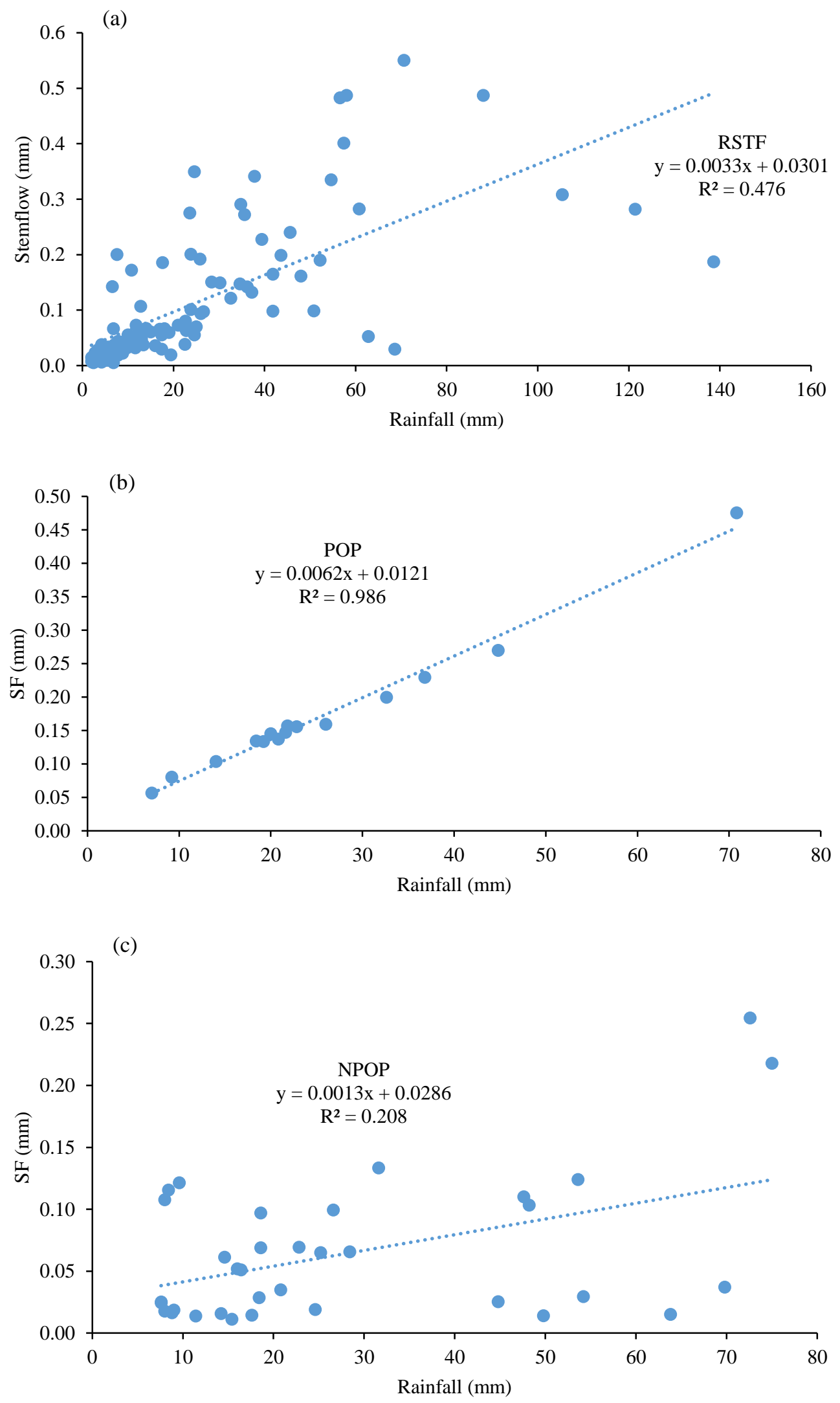

Figure 6. Regression of $S f_{d}$ against $R_{d}$ for (a) regenerated secondary tropical forest (RSTF); (b) productive oil palm plantation (POP); and (c) non-productive oil palm area (NPOP). 
Table 5. Funneling ratio (FR), $\mathrm{S} f_{d}$ and interception loss values for RSTF, POP and NPOP.

\begin{tabular}{cccc}
\hline & RSTF & POP & NPOP \\
\hline Range of FR & $0.44-4.73$ & $1.4-4.4$ & $0.8-6.9$ \\
FR average & 1.9 & 2.6 & 2.4 \\
SF $(\%)$ & 0.46 & 0.67 & 0.41 \\
Interception loss $(\%)$ & 28.3 & 9.1 & 12.2 \\
\hline
\end{tabular}

Notes: RSTF=regenerated secondary tropical forest; $\mathrm{POP}=$ productive oil palm plantation; $\mathrm{NPOP}=$ non-productive oil palm area.

The funneling ratios computed in this study ranged from $0.44-4.73,1.4-4.4$ and $0.8-6.9$ for RSTF, POP and NPOP, respectively. Based on sampled trunk basal area of RSTF $(15.8$ $\left.\mathrm{m}^{2} / \mathrm{ha}\right)$, POP $\left(18.6 \mathrm{~m}^{2} / \mathrm{ha}\right)$ and NPOP $(16.5$ $\mathrm{m}^{2} / \mathrm{ha}$ ) and the computed funneling ratio of these trunks of RSTF (1.9), POP (2.6) and NPOP (2.4), indicating that $0.46 \%$ (RSTF), $0.67 \%$ (POP) and $0.41 \%$ (NPOP) of rainfall intercepted by the projected canopy area were diverted in $\mathrm{S} f_{d}$. These findings were lower compared to other studies elsewhere under different vegetation types. Such low observations of $\mathrm{S} f_{d}$ might be linked to measurement method as suggested by Geoffery (2013) that indicates significant leakage may occur if the routed rubber collar installed at trunk is not properly fitted and sealed. Elsewhere, Germer et al. (2010) suggested that large stand might generate more $\mathrm{S} f_{d}$ yield than medium-sized stand, but small stand was found to be of no different with the two larger sizes. Canopy density also plays important role to $\mathrm{S} f_{d}$ generation, less density may generate higher $\mathrm{S} f_{d}$ meanwhile high density of canopies may decrease the $\mathrm{S} f_{d}$ (Siegert \& Levia, 2014). $\mathrm{S} f_{d}$ volume at POP generated large volume and thus, this finding need further attention for consideration of land management, especially for a productive oil palm plantation.

\section{Interception Loss}

The measured interception loss $\left(E_{i}\right)$ computed at RSTF was $549.5 \mathrm{~mm}$ or $22.3 \%$ of the gross rainfall (Table 6). This is slightly higher than the $21.3 \%$ reported by Vernimem et al. (2007) in stunted heath forest, central of Kalimantan, Indonesia. Elsewhere, a study by Burghouts et al. (1998) in Sabah, Malaysia and Dykes (1997) in Brunei reported that $19 \%$ and $18 \%$ of rainfall, respectively, were accounted as $E_{i}$ under lowland evergreen tropical forest canopy. Such a slightly higher $E_{i}$ value obtained in this study might be attributed to the measured $S f_{d}$ which was significantly lower compared to those reported elsewhere. This might be due to leakage that occurred if the rubber collar is not properly fitted and sealed.

In other Southeast Asian region, a logged-over lowland forest $E_{i}$ of $19 \%$ and $20 \%$ were reported in Sabah, Malaysia (Chappell et al., 2001) and Sarawak (Kumagai et al., 2005), respectively. In the central Sulawesi, the interception loss under logged forests and natural tropical rainforests were of $18-20 \%$ and $30 \%$, respectively (Diezt et al., 2006). The $E_{i}$ value under RSTF in this study showed almost similar findings with those areas with disturbed forest structures due to logging activities. Thus, it is suggested that $E_{i}$ value might be controlled by vegetation structures and density.

In this study, RSTF was capable to entrain more incidental rainfall and generate higher $E_{i}$ compared to POP and NPOP, which contributed about $8.2 \%$ and $12.2 \%$ of $E_{i}$, respectively. Lower $E_{i}$ values obtained from these two oil palm canopies were due to a shorter study period for both sites. This happen due to unforeseen circumstances such as POP plantation area cleared for newly planting management plan. The data collected under NPOP was of shorter duration due to rain gauge faulty and inconsistency of results obtained from the automated logger. Thus, only four months of purely precise and stable results were used for further analysis. Other study on oil palm canopy in Peninsular Malaysia by Kee et al. (2000) reported that $17 \%$ of rainfall was estimated as $E_{i}$. Compared to Geoffery (2013), the $E_{i}$ value under oil palm plantation was $28.9 \%$. The high $E_{i}$ value was associated with La Nina phenomenon during the two years of when the study was carried out.

In addition, some argued that rainfall interception loss in Southeast Asia may be at least two folds higher than those reported for Central Amazonia; this was possibly because of large-scale advection from the surrounding warm sea (Schellekens, 2000; Bruijnzeel, 2004). Furthermore, the partitioning of rainfall into throughfall, stemflow and interception loss were 
affected by three primary factors, i.e. rainfall characteristics, meteorological factors and vegetation structure (Crockford \& Richardson, 2000; Staelen et al., 2007).

The $E_{i}$ value of RSTF revealed better relationship with rainfall depth compared to POP and NPOP. The pattern of $E_{i}$ against $R_{d}$ in Figure 7 showed that whenever $R_{d}$ is low, the $E_{i}$ value increase, and vice versa if $R_{d}$ increase, the $E_{i}$ becomes low. This revealed an inverse relationship between $E_{i}$ and $R_{d}$ for RSTF, POP and NPOP. In addition, the relationship pattern among the three sites also demonstrated only a few storm events (> $50 \mathrm{~mm}$ ) recorded during the study period.

This study suggests that oil palm trunk morphology and physical including amounts of fronds play an important role in influencing $E_{i}$ values, especially different ages among the tree or trunk samples.

\section{Comparison with Other Studies}

This study revealed substantial correlation between $E_{i}$ and $R_{d}$ at all study sites. The $E_{i}$ values were found to vary considerably among the three vegetative types. As for RSTF, POP and NPOP, about $77.7 \%, 91.8 \%$ and $87.8 \%$ of $R_{d}$, respectively, reaches the ground surface which is considered as interception storage (Table 6). This interception storage is important to be estimated and should not be neglected as it may have an impact on tree growth or oil palm fruits production. The average percentage of stemflow is normally low compared to throughfall and even negligible in some studies. However, Germer et al. (2010) reported that the variability of stemflow generation at tropical rainforest sites is still remarkable.

\section{CONCLUSION}

The results revealed that $E_{i}$ characteristics of RSTF, POP and NPOP in Bintulu, Sarawak varied among the study sites due to duration of data collection and suggested to be site specific even under the same tropical condition. However, the $E_{i}$ values under RSTF showed a similar pattern compared to logged mover tropical forest elsewhere. Thus, this study suggests that the disturbance of canopy and forest density may contribute to $E_{i}$ value. The variabilities of $T f_{d}$ and $S f_{d}$ values obtained in this study suggest that these parameters were influenced by canopy structures and trunk morphology, local meteorological condition, installation of sampling material and age of sampling tree or trunk. Although the results of interception loss achieved at these study sites were considerably acceptable, future research is needed in order to establish a reliable interception component, which is vital for managing forest resources, oil palm plantation as well as catchment area for water resources.

Table 6. Rainfall separating at RSTF, POP and NPOP in Sarawak, Borneo and elsewhere within tropic regions.

\begin{tabular}{lcccccl}
\hline \multicolumn{1}{c}{ Location } & $\begin{array}{c}\text { Forest } \\
\text { type }\end{array}$ & $\begin{array}{c}R_{d} \\
(\mathrm{~mm})\end{array}$ & $\begin{array}{c}T f_{d} \\
(\%)\end{array}$ & $\begin{array}{c}S f_{d} \\
(\%)\end{array}$ & $\begin{array}{c}E_{i} \\
(\%)\end{array}$ & \multicolumn{1}{c}{ References } \\
\hline Central Kalimantan & LERF & $2200^{\mathrm{a}}$ & 87.2 & 1.4 & 11.4 & Asdak et al. $(1998)$ \\
Central Kalimantan & LERF & 2995 & 82.8 & 0.8 & 16.4 & Vernimmen et al. $(2007)$ \\
Sabah, Malaysia & LERF & 3100 & 80.7 & 1.9 & 17.4 & Sinun et al. $(1992)$ \\
Sabah, Malaysia & LERF & 2800 & 80.0 & 1.0 & 19.0 & Burghouts et al. $(1998)$ \\
Sabah, Malaysia & LERF & $1400^{\mathrm{b}}$ & 92.0 & 1.1 & 6.9 & Bidin \& Chappel (2003) \\
Brunei & LERF & $825^{\mathrm{c}}$ & 81.0 & 1.0 & 18.0 & Dykes (1997) \\
Sarawak, Malaysia & LERF & 2360 & 84.5 & 3.1 & 12.4 & Manfroi et al. $(2004)$ \\
Colombian Amazonia & LERF & 3400 & $81.9-87.2$ & $0.9-1.5$ & $12.0-17.0$ & Marin et al. $(2000)$ \\
Venezuela & LERF & 3665 & 87.0 & 7.1 & 5.9 & Sf from Jordan, 1978; $f_{d}$ \\
& & & & & & from Jordan and Heuveldop \\
& & & & & & (1981) \\
Venezuela & THF & 3500 & 90.5 & 1.5 & 8.0 & Herrera (1979) \\
Central Kalimantan & THF & 2995 & 89.1 & 1.3 & 9.6 & Vernimmen et al. $(2007)$ \\
Central Kalimantan & SHF & 2995 & 76.7 & 2.0 & 21.3 & Vernimmen et al. $(2007)$ \\
Eastern Tibet, China & CF & 2200 & 24.2 & 0.1 & 75.7 & Liu et al. (2013) \\
Sedenak, Johore, & POP & 2830 & 66.9 & 4.2 & 28.9 & Geoffery (2013) \\
Malaysia & & & & & & \\
Sarawak, Malaysia & RSTF & 2466.9 & 77.2 & 0.5 & 22.3 & This study \\
Sarawak, Malaysia & POP & $385.8^{\mathrm{d}}$ & 91.1 & 0.7 & 8.2 & This study \\
Sarawak, Malaysia & NPOP & $1144^{\mathrm{c}}$ & 87.4 & 0.4 & 12.2 & This study \\
\hline
\end{tabular}

Notes: Lowland Evergreen Rain Forest (LERF), Tall Heath Forest (THF), stunted Heath Forest (SHF), rainfall $\left(R_{d}\right)$, throughfall $\left(T f_{d}\right)$, stemflow $\left(S f_{d}\right)$ and interception $\left(E_{i}\right)$.

a -6 month; ${ }^{\mathrm{b}}$-Very dry period; ${ }^{\mathrm{c}}-4$ months; ${ }^{\mathrm{d}}-3$ months. 
(a)

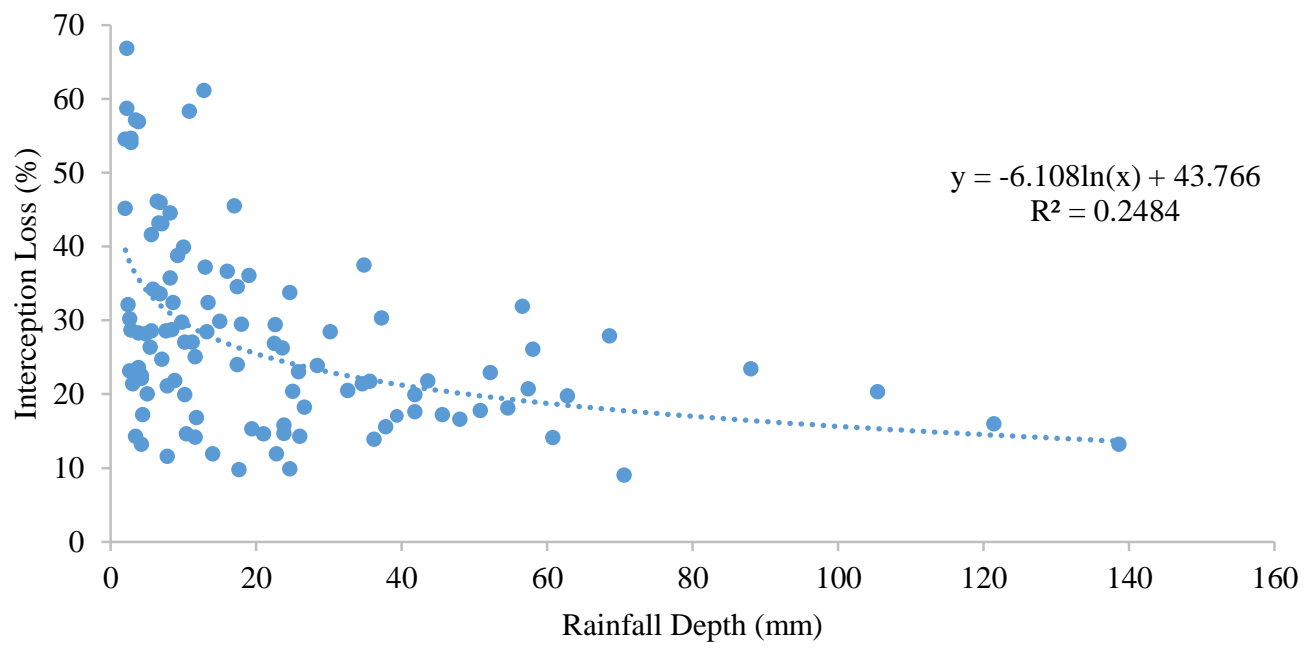

(b)

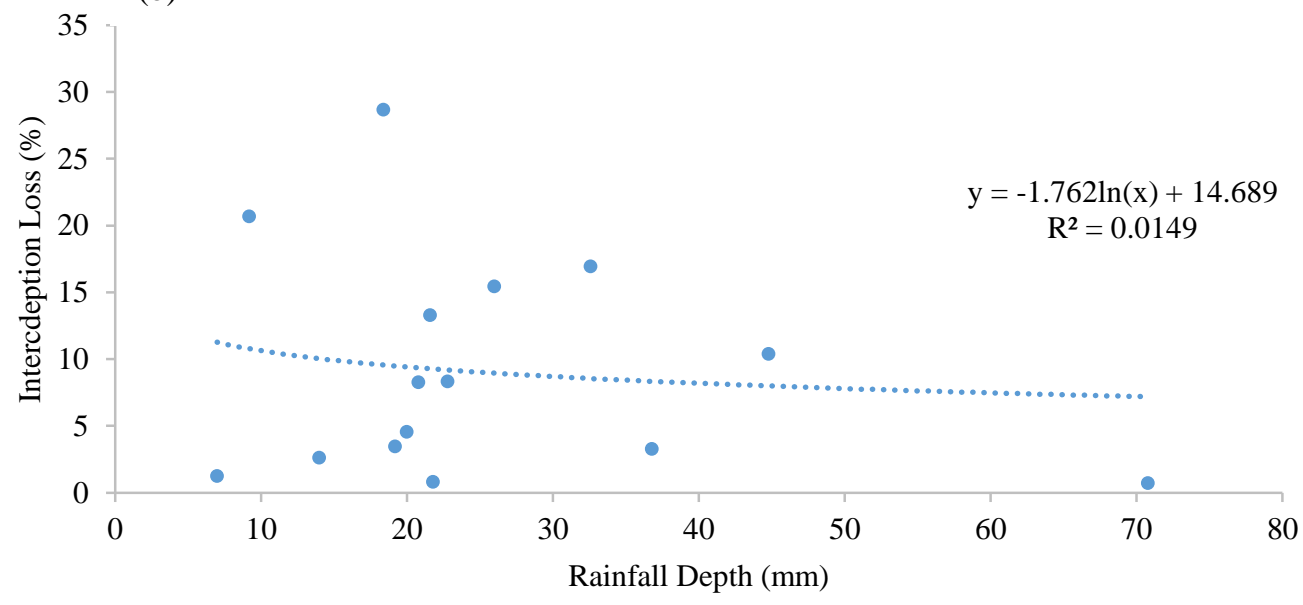

(c)

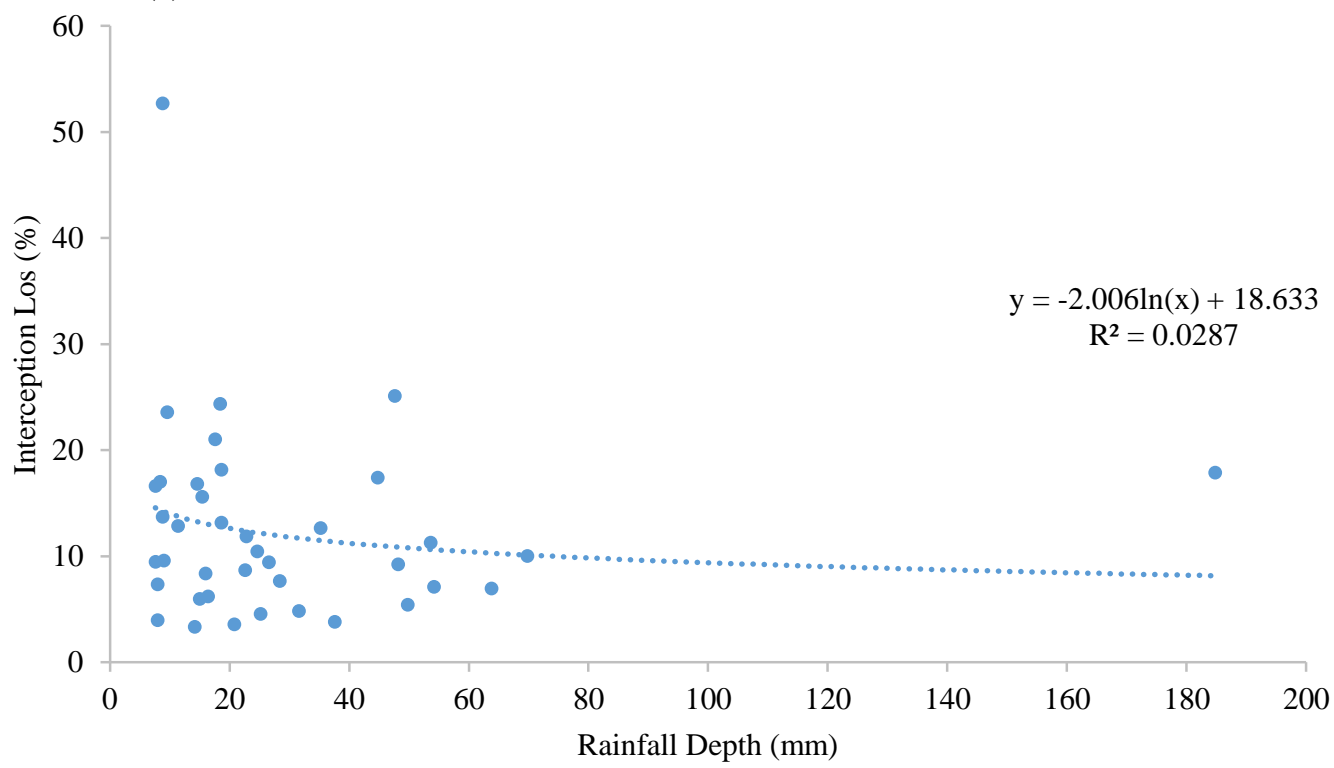

Figure 7. Inverse relationship between $E_{i}$ and $R_{d}$ at (a) regenerated secondary tropical forest (RSTF); (b) productive oil palm plantation (POP); and (c) non-productive oil palm area (NPOP). 


\section{ACKNOWLEDGEMENTS}

The authors would like to acknowledge the financial support received from the Universiti Putra Malaysia through research grant (GPIPS/2016/9488600). Also, thank you to the associate editor and anonymous reviewers for good comments to improve this manuscript.

\section{REFERENCES}

Abdullah, S.A. \& Nakagoshi, N. (2007). Forest fragmentation and its correlation to human land use change in the state of Selangor, Peninsular Malaysia. Forest Ecology and Management, 241(1-3): 39-48.

Asdak, C., Jarvis, P.G., Van Gardingen, P. \& Fraser, A. (1998). Rainfall interception loss in unlogged and logged forest areas of Central Kalimantan, Indonesia. Journal of Hydrology, 206(3-4): 237244.

Banabas, M., Turner, M.A., Scotter, D.R. \& Nelson, P.N. (2008). Losses of nitrogen fertiliser under oil palm in Papua New Guinea: 1. Water balance, and nitrogen in soil solution and runoff. Australian Journal of Soil Research, 46(4): 332-339.

Bidin, K. \& Chappell, N.A. (2003). First evidence of a structured and dynamic spatial pattern of rainfall within a small humid tropical catchment. Hydrology and Earth System Sciences, 7(2): 245253.

Bruijnzeel, L.A. (2004). Hydrological functions of tropical forests: not seeing the soil for the trees? Agriculture, Ecosystems and Environment, 104(1): 185-228.

Burghouts, T.B.A., Van Straalen, N.M. \& Bruijnzeel, L.A. (1998). Spatial heterogeneity of element and litter turnover in a Bornean rain forest. Journal of Tropical Ecology, 14(4): 477-506.

Chappell, N.A., Bidin, K. \& Tych, W. (2001). Modelling rainfall and canopy controls on netprecipitation beneath selectively-logged tropical forest. Plant Ecology, 153(1-2): 215-229.

Corley, R.H.V. \& Gray, B.S. (1976). Growth and morphology. In Corley, R.H.V., Hardon, J.J. \& Wood, B.J. (Eds.), Oil palm research: developments in crop science 1. Amsterdam: Elsevier. Pp. 7-21.

Crockford, R.H. \& Richardson, D.P. (1990). Partitioning of rainfall in a eucalypt forest and pine plantation in southeastern Australia: IV the relationship of interception and canopy storage capacity, the interception of these forests, and the effect on interception of thinning the pine plantation. Hydrological Processes, 4(2): 169188.
Crockford, R.H. \& Richardson, D.P. (2000). Partitioning of rainfall into throughfall, stemflow and interception: effect of forest type, ground cover and climate. Hydrological Processes, 14(1617): 2903-2920.

Deguchi, A., Hattori, S. \& Park, H. (2006). The influence of seasonal changes in canopy structure on interception loss: application of the revised Gash model. Journal of Hydrology, 318(1-4): 80102.

Dietz, J., Hölscher, D., Leuschner, C. \& Hendrayanto, H. (2006). Rainfall partitioning in relation to forest structure in differently managed montane forest stands in Central Sulawesi, Indonesia. Forest Ecology and Management, 237(1): 170-178.

Dykes, A.P. (1997). Rainfall interception from a lowland tropical rainforest in Brunei. Journal of Hydrology, 200(1-4): 260-279.

Gash, J.H.C. \& Stewart, J.B. (1977). The evaporation from Thetford Forest during 1975. Journal of Hydrology, 35(3-4): 385-396.

Geoffery, J.G. (2013). Partitioning of rainfall and flowpath processes in small oil palm catchments (Ph.D. Thesis). Universiti Teknologi Malaysia, Malaysia.

Geoffery, J.G. \& Yusop, Z. (2005). Bed load transport from a regenerated forest catchment in Sarawak. Jurnal Kejuruteraan Awam, 17(2): 69-72.

Germer, S., Werther, L. \& Elsenbeer, H. (2010). Have we underestimated stemflow? Lessons from an open tropical rainforest. Journal of Hydrology, 395(3-4): 169-179.

Hartley, C.W.S. (1988). The oil palm (Elaeis guineensis Jacq.). England: Longman Scientific and Technical.

Herrera, R.A. (1979). Nutrient distribution and cycling in an Amazon Caatinga forest on Spodosols in Southern Venezuela. (Ph.D. Thesis). University of Reading, United Kingdom.

Herwitz, S.R. (1986). Infiltration-excess caused by stemflow in a cyclone-prone tropical rainforest. Earth Surface Processes and Landforms, 11(4): 401-412.

Jordan, C.F. (1978). Stem flow and nutrient transfer in a tropical rainforest. Oikos, 31(2): 257-263.

Jordan, C.F. \& Heuveldop, J. (1981). The water budget of an Amazonian rainforest. Acta Amazonica, 11(1): 87-92.

Junior, R.C.O., Keller, M.M., Ramos, J.F.F., Beldini, T.P., Crill, P.M., de Camargo, P.B. \& van Haren, J. (2015). Chemical analysis of rainfall and throughfall in the Tapajós National Forest, Belterra, Pará, Brazil. Revista Ambiente and Água, 10(2): 263-285. 
Kee, K.K., Goh, K.J. \& Chew, P.S. (2000). Water cycling and balance in a mature oil palm agroecosystem in Malaysia. In Pusparajah, E. (Ed.), Proceedings of the International Planters Conference on Plantation Tree Crops in the New Millennium: The Way Ahead, May 17-20 Kuala Lumpur, Malaysia: The Incorporated Society of Planters. Pp. 153-169.

Kumagai, T.O., Saitoh, T.M., Sato, Y., Takahashi, H., Manfroi, O.J., Morooka, T. \& Komatsu, H. (2005). Annual water balance and seasonality of evapotranspiration in a Bornean tropical rainforest. Agricultural and Forest Meteorology, 128(1-2): 81-92.

Levia Jr., D.F. \& Frost, E.E. (2003). A review and evaluation of stemflow literature in the hydrologic and biogeochemical cycles of forested and agricultural ecosystems. Journal of Hydrology, 274(1-4): 1-29.

Liu, G., Du, S., Peng, S. \& Wang, G. (2013). Rainfall interception in two contrasting forest types in the Mount Gongga area of Eastern Tibet, China. Hydrology Current Research, 4(4): 1-6.

Llyod, C.R. \& Marques, A.O. (1988). Spatial variability of throughfall and stemflow measurements in Amazonian rainforest. Agricultural and Forest Meteorology, 42(1): 6373.

Loustau, D., Berbigier, P., Granier, A. \& Moussa, F.E.H. (1992). Interception loss, throughfall and stemflow in a maritime pine stand. I. Variability of throughfall and stemflow beneath the pine canopy. Journal of Hydrology, 138(3-4): 449467.

Manfroi, O.J., Koichiro, K., Nobuaki, T., Masakazu, S., Nakagawa, M., Nakashizuka, T. \& Chong, L. (2004). The stemflow of trees in a Bornean lowland tropical forest. Hydrological Processes, 18(13): 2455-2474.

Marin, C.T., Bouten, W. \& Sevink, J. (2000). Gross rainfall and its partitioning into throughfall, stemflow and evaporation of intercepted water in four forest ecosystems in western Amazonia. Journal of Hydrology, 237(1): 40-57.

Md Noor, M.R. \& Harun, M.H. (2004). The role of leaf area index (LAI) in oil palm. Oil Palm Bulletin, 48: 11-16.

Murakami, S. (2006). A proposal for a new forest canopy interception mechanism: splash droplet evaporation. Journal of Hydrology, 319(1-4): 7282.

Reid, L.M. \& Lewis, J. (2009). Rates, timing and mechanisms of rainfall interception loss in a coastal redwood forest. Journal of Hydrology, 375(3-4): 459-470.
Sahin, V. \& Hall, M.J. (1996). The effects of afforestation and deforestation on water yields. Journal of Hydrology, 178(1-4): 293-309.

Scatena, F.N. (1990). Watershed scale rainfall interception on two forested watersheds in the Luquillo Mountains of Puerto Rico. Journal of Hydrology, 113(1-4): 89-102.

Schellekens, J. (2000). The interception and runoff generating processes in the Bisley catchment, Luquillo experimental forest, Puerto Rico. Physics and Chemistry of the Earth, Part B: Hydrology, Oceans and Atmosphere, 25(7-8): 659-664.

Schroth, G., Ferreira Da Silva, L., Wolf, M., Teixeira, W.G. \& Zech, W. (1999). Distribution of throughfall and stemflow in multi-strata agroforestry, perennial monoculture, fallow and primary forest in central Amazonia, Brazil. Hydrological Processes, 13(10): 1423-1436.

Siegert, C.M. \& Levia, D.F. (2014). Seasonal and meteorological effects on differential stemflow funneling ratios for two deciduous tree species. Journal of Hydrology, 519: 446-454.

Silva, I.C. \& Okumura, T.J. (1996). Throughfall, stemflow and interception loss in a mixed white oak forest (Quercus serrata Thunb.). Journal of Forest Research, 1(3): 123-129.

Sinun, W., Meng, W.W., Douglas, I. \& Spencer, T. (1992). Throughfall, stemflow, overland flow and throughflow in the Ulu Segama rainforest, Sabah, Malaysia. Philosophical Transactions of the Royal Society B: Biological Sciences, 335(1275): 389395.

Slamet, B., Jaya, I.N.S., Hendrayanto, H. \& Tarigan, S.D. (2015). Stemflow variability in tropical lowland forest landscape transformation system: case study at Jambi Province, Indonesia. Jurnal Manajemen Hutan Tropika, 21(1): 1-10.

Staelens, J., De Schrijver, A. \& Verheyen, K. (2007). Seasonal variation in throughfall and stemflow chemistry beneath a European beech (Fagus sylvatica) tree in relation to canopy phenology. Canadian Journal of Forest Research, 37(8): 1359-1372.

Vernimmen, R.R.E., Bruijnzeel, L.A., Romdoni, A. \& Proctor, J. (2007). Rainfall interception in three contrasting lowland rainforest types in Central Kalimantan, Indonesia. Journal of Hydrology, 340(3-4): 217-232.

Yusof, B. \& Chan, K.W. (2004). The oil palm and its sustainability. Journal of Oil Palm Research, 16(1): 1-10.

Zhang, G., Zeng, G.M., Jiang, Y.M., Huang, G.H., Li, J.B., Yao, J.M., Tan, W., Xiang, R. \& Zhang, X.L. (2006). Modelling and measurement of two-layercanopy interception losses in a subtropical evergreen forest of central-south China. Hydrology and Earth System Sciences, 10(1): 6577. 